\title{
WILLS EXECUTED UNDER MISTAKE OF FACT.
}

The question of what is the legal effect of a will executed under mistake of fact dates back to the time of Cicero and the principles of Roman law are its foundation.

By civil law the heir could not be disinherited without good reason, ${ }^{1}$ and it is from this the Roman law on the subject of revocation by mistake of fact springs.

The mistake of fact might be a mistake as to the person named or a mistake in the motive or reason of the testator.

As to the mistake in the person named at Roman law an error as to the person invalidated the will, and if the testator intended to insert $A$ as his heir and by error inserted $B$, the inheritance falls. But it was not every error which rendered a will invalid; a false description did not if it could be ascertained who was meant: Dropsie on Roman Law, p. I 15.

An error in the motive of the testator always rendered the disposition invalid. Thus, if the testator intended to insert $A$, but believing him to be dead when he was not dead, inserted $B$, the former will be the heir. ${ }^{2}$ So it was held by Cicero that if a father disinherited a son for some special reason and the reason is proved to be a mistake, the son will inherit ${ }^{3}$ and the converse is also true, that where a man made another his. heir and subsequently found out that he was not his heir the will would be revoked."

Further, it would seem that the Roman law rule, which was adopted by the common law, that a change of circumstances $^{5}$ in the family of the testator revoked the will, was based on the reason of mistake of fact in the mind of the testator as to who was his heir. ${ }^{6}$ Although the reason given

2 d Inst. 18 to $\mathrm{r}$.

2 Digest, 28-5; Dropsie on Roman I.aw, p. 43.

3 I C. 388 .

I Justinian Pandects, C. 92, Dig. XXVIII, Title X.

5 Salkowski's Roman Law, p. 839; Doe v. Lancaster, 5 Term Rep. 58, 5 Ed. ; I Jarman on Wills, I24.

6 Hamill's San'd Just. 256. 
by the common law judges for the rule is that a "tacit condition is annexed to the will itself that a change of circumstances will revoke it." 1

The mistake of fact may arise at the time of the making of the will or from a change of circumstances after the making of the will. As to the latter, which includes the subject of subsequent birth, marriage or other change of circumstances of the family, it is outside the domain of the present article which deals with mistakes of fact arising at the execution of the will, and not such as arise after it is made by presumption of law, which is fully discussed in Young's Appeal, 80 American Dec. 517 , and the note to the case, and is largely regulated in Pennsylvania by the Act of April 8, 1833 .

What, then, is the legal effect of a will executed under a mistake of fact? In the first place, if there is to be any relief from a mistake of fact or a mistake of any kind, it must be found in a court of equity. ${ }^{2}$ We have seen that the mistake in a will may be as to the person or estate named or it may be as to the motive. As to mistakes of fact in the person or estate named the law is very plain, and although it is hard to sometimes distinguish between the cases, the principles are so clear, and the cases have been so thoroughly gone over that a lengthy discussion on the subject is needless. ${ }^{3}$

It is a general rule that a court of equity will only relieve such mistakes of fact when they appear on the face of the will, and this is founded on the principle that, since the Statute of Frauds, the intention of the testator as expressed in the will cannot be altered by evidence de hors the will." (For a general discussion of mistakes of fact in the subject matter of the will or persons and estate named, see $66 \mathrm{Am}$. Dec. p. 630, where it is fully gone into.)

The question of what is the legal effect of a mistake of fact

${ }^{2}$ Doe v. Lancaster, supra; Brush v. Williams, 4 John. Chan. 506.

"Suell $v$. Atlantic Co., 18 L. R. 79; Whelen's Appeal, 70 Pa. 410; McCaul v. Davis, 56 Pa. 435 : Kemble v. Coal Co., 90 Pa. 344.

' 15 Am. \& Eng. Ency. 663; I Jarman on Wills, 334, * p. 379; I Story's Eq. Jur. 99 ; I Red. on Wills, 3d Ed. $50 \mathrm{r}$; Kerr on Fraud, 448.

' I Jarman, * p. 379 ; I Story's Eq. Jur. 99 ; Wallize $v$. Wallize, 55 Pa. 24 ; I Red. on Wills, 498. 
in a will when the mistake is in the motive of the testator has never been decided by the Supreme Court of any state. In Padelford's Estate, I90 Pa. 35 (1 899), the facts were as follows: One Arthur Padelford married, and a child was born by his wife during the marriage, subsequently he obtained a divorce and later made his will. In his will he said, that the child was not his child, and he therefore did not leave her anything. A bill was filed by the child's grandparents to compel Padelford to recognize the child as his. This he did by a written agreement, and the question which arose at the audit was whether the will was revoked pro tanto by the mistake of fact as to the child's paternity, so that she could inherit as under the intestate laws. The auditing judge held that there had been a mistake of fact and that the will would be revoked on that account. But the Orphans' Court on hearing exceptions, although granting that a mistake "may perhaps" revoke a will, decided that Padelford's Estate did not come within the principle. The court holding " that a presumption arising from facts occurring after the execution of a will depending for its establishment upon proof of external circumstances may be overcome by proof of the same character." And, therefore, it might be shown what the belief of the testator really was as to the child's paternity. The Supreme Court affirmed this opinion of the lower court for the reasons as stated in the lower court's opinion. So that the question of whether a will can be revoked by a mistake of fact is still unanswered.

This question Judge Sharswood asked in Baxter's Appeal, but does not answer, although from his decision it would seem that the Roman law would be adopted. In that case all that was decided was that an issue devisavit vel non cannot be had to prove whether a testator was laboring under a mistake as to the legitimacy of his child, for if it did revoke the will, it was only pro tanto and it would be a claim against the estate on the filing of the account. As to this see, also, Doane v. Lake, 32 Me. 268. Judge Sharswood cites the case in Cicero's Oration, I C. 38. where a father gave an estate to a stranger under the mistaken belief that his son was dead, and it was

${ }^{1}$ I Brewster, p. 159. 
held that the son would be instituted in his place. He also cites Swinburne on Wills, p. 395, where the rule is laid down that if the testator expresses a false cause, as because my son is dead thou shalt be executor, the disposition is of no force. From which it would seem that the Roman law would be adopted. In Kendall v. Abbott, 4 Ves. Jr. *p. 802 (1790), where a legacy was given to a man as husband, a character which he had falsely assumed, it was held that the civil law would be adopted; but it would seem that in that case the reason for adopting it was the fraud. A similar case arose in Wilkinson v. Johnson, L. R. 2d. Eq. 319 (1866), and the same conclusion was reached. Lord Mansfield, in Brady v. Cubit, Doug. 30 ( 1778 ), cites Cicero's case, and there is a dictum in Gordon v. Gordon, I Mer. I4I (1816), to the same effect.

There seems to be no doubt that where a will is revoked under a mistake of fact the revocation can be set aside. The principle is stated in Williams on Executors, p. 147, and in numerous cases. In the case of Doe v. Evans, to Adol \& Ellis, 228 ( 1839 ), the testator devised land to $L$ with remainder to his first and other sons and daughter. $L$ died, and his son died and left a posthumous daughter whose existence was not known to the testator when he revoked the will, reciting the death of $\mathrm{L}$ without issue. Held to be only a conditional revocation, the testator having become acquainted with its existence before his death. [See also Campbell v. French, 3 Ves. * 32 I ( 1787$)$ ].

In Mendehall's Appeal, r24 Pa. 387 (1889), the principal as stated was adopted in this state, and it was held that a codicil which revokes a will, if made under a mistake of fact, is void generally. But it modified the rule to suit that case, and held that where the falsity of the alleged fact rested on the personal knowledge of the testator it would not revoke the codicil. In that case the testator revoked a devise by a codicil because of a gift to the legatee in his lifetime, and it was shown that there was no gift, but it was held the codicil would stand. That case carries out the theory that it is the intention of the testator which will be considered in revocation of a will, and when the 
falsity is something which he could have known all about, it is presumed the full facts are known to him.

The reason given for the rule that a revocation made by mistake can be set aside is, that it is a conditional revocation and when the condition fails the revocation fails. It may be argued, however, that a revocation under a mistake of facts is in no way similar to a making of a will under a mistake, and that a will is ambulatory during the life of the testator and contingent on his death, but a revocation takes effect immediately: § 2, Hare \& Wallace Leading Am. Cases, 517 . Further, the destruction or cancellation of a will under statute is only prima facie evidence of revocation and may be rebutted by proof of a mistake for that reason : 2 Hare \& Wallace, $50 \dot{r}$.

But why is not the operation of the will conditional on the truth of the reason for the devise in it, in the same manner that the revocation of a will is conditional? It may be said that the Wills act has provided in what manner a will can be revoked and a mistake of fact is not one of the ways-provided by statute, and that a will cannot be revoked by word of mouth or subsequent circumstances unless the circumstances amount to a revocation at law. Further, that parol evidence dehors the will cannot be admitted to prove a mistake or to show that the testator intended to dispose of his property differently, ${ }^{2}$ and that the mistake must appear on the face of the will as already stated.

First of all, it must be remembered that a mistake in a contract or a will does not make it void, but equity will rectify the mistake, ${ }^{3}$ and that the will is not really revoked by the mistake but only corrected to suit the intention of the testator, which is what pro tanto revocation is.

And, second, that although when a testator gives his property to $A$, and a false reason is found on the will; or can be gathered from it, although the mistake does not appear on the face of the will, as soon as the facts as stated or reason as

\footnotetext{
${ }^{1}$ Rothmaler $v$. Meyers, 4 Dessaus, 215 ; Flinthan $v$. Bradford, 10 Pa. 82 ; Williams v. Freeman, 83 N. Y. 56r ; Lewis v. Iord, 2 W. \& S. 455.

${ }^{2}$ Wallize $v$. Wallize, 55 Pa. 242; I Redf. 499; Avery $v$. Chappel, 6 Conn. 270.

S Avery v. Chappel, 6 Conn. 270.
} 
given is shown to be false, the mistake appears on the face of this will, and in Durham v. Avery, 45 Conn. 61 (1877), it is said that " it is the reason that must appear on the face of the revocation, where it is sought to set the revocation aside for a mistake of fact," and it is a rule that where a testator founds his revocation on his advice or belief merely instead of making the death of the legatee (when he was not dead) the reason of the revocation, it will stand. ${ }^{1}$

The case of Gifford v. Dyer, 2 R. I. 99 (1852), is a very near case to that of Cicero. In that case a testator made a will.under a mistalke as to the supposed death of her son, but the reason for the devise, viz., the death of the son, did not appear in the will itself. It was held that the mistake must appear on the face of the will, and it also must be shown on the will what it would have been but for the mistake. In Bramby v. Haines, I Lees' Cases, I20 (I833), it was held that where a woman made a will describing herself as a widow on the presumption that her husband was dead, that it would be revoked if he were not dead. So that a false reason revokes the devise.

Further, it must be remembered, that there is no material difference in principle between the rules for interpretation of wills and contracts, ${ }^{2}$ and in Pennsylvania parol evidence to show the inducement under which a contract is entered into is admissible. $^{3} \quad$ From which it would seem that the inducement under which a will is executed might be shown by parol evidence. But the courts, from the cases already cited, will not allow evidence of intention of the testator to be given generally, and it is therefore doubtful, even if the intention amounts to an inducement, whether the court will allow it to be given. But where the intention of the testator appears on the face of the will in the reason given, the intention is not altered in any way by showing the reason to be false, for the condition is part of the intention.

Therefore, it would seem that a devise should be set aside

${ }^{1}$ Atty. Gen. v. Lloyd, 3 Atl. 552; Atty. Gen. v. Ward, 3 Ves. 327 ; I Jar. Perkin's Note, I66.

${ }^{2}$ Greenleaf, Evidence, \& 287 ; Stephen on Evidence, Note, p. I6r.

${ }^{3}$ Greenwalt $v$. Kline, 85 Pa. 369. 
by the mistake of the fact at the time the will is executed, and the subsequent discovery of the mistake need not enter into the question, and we have seen that; under the parol evidence rulc, the ground on which the mistake is shown is that it was a conditional devise, and when the condition fails the devise fails.

Where the testator subsequently discovers, and by another writing corrects his mistake, the case is much strengthened, for then the question of a change of circumstances in the family arises, and under Young's Appeal, $39 \mathrm{~Pa}$. II 5 (1861), it would seem that there would be a pro tanto revocation, since whenever there is a change of circumstances in the family ot the testator which imposes on him a new moral duty, the will is revoked. Which case follows the Roman principle.

It is very doubtful whether the subsequent discovery, say of the existence of a child, is a sufficient change of circumstances to revoke a will by itself at common law, and in McCullough's Appeal ${ }^{1}$ it was decided that the Wills act only applied to " physical birth," so that there could be no recovery under the statute. The case of Ordish v. Dermott, 2 Redfield (N. Y.) 460 ( 1877$)$, would seem to be in point. In that case it was held that a will made in ignorance of the existence of a living child is not revoked by its discovery. That case rested entirely on the principle that the birth of a child was not of itself, without marriage, a sufficient change of circumstances to revoke a will, according to the well-known rule of common law.

The theory expressed in Young's Appeal, therefore, seems inconsistent with the common law theory that marriage and birth are both required to revoke the will." And it is diffcult to see why the Roman law should be adopted.

In conclusion it would seem that a will executed under a mistake of fact should be revoked if the reason for the devise appears on the face of the will. Further, that the proper method for the question to arise is not at the probate of the will since revocation is pro tanto, and mistake is unlike fraud, in that the latter will revoke the entire will, while the former comes to the court of equity merely for correction.

\section{Jolin Lawrence Wetherill.}

1 Ir5 Pa. 247 ; also Campbell $v$. Jamieson, 8 Pa. 488.

2 Williams on Exe'r, p, 241. 